\title{
DEVELOPMENT OF QUALITY CONTROL OF SME PRODUCTS IN MERUYA SELATAN KELURAHAN - JAKARTA BARAT
}

\author{
Tukhas Shilul Imaroh \\ Universitas Mercu Buana Jakarta, Indonesia.
}

\begin{abstract}
This community service is done to encourage the community to be creative and independent with entrepreneurs. Activities can be carried out by partnering, building partnerships will make it easier and more excited. The people of Meruya Selatan village have partnered with the PKK and Menara Child-Friendly Integrated Public Space (RPTRA), also to help one of the DKI Jakarta government programs.

The community of South Meruya Village has been carrying out production activities, if there is a desire or order, for this reason, it is necessary to increase the scale of production and marketing, beginning with improvements in the production process and product quality, it is hoped that they will understand and have an awareness of the importance of product quality.

After training and assistance in the production of bags made of coffee, decorative flowers and souvenirs for SME people in Meruya Selatan village together with PKK women, they became more aware of the need to set quality standards for products made, product quality expectations of buyers / consumers to have a sustainable business business. Furthermore, it becomes important to produce sustainable products by building commitment, and producing products that meet market needs and are different from the others.
\end{abstract}

Keywords: SME Products, Product Quality Standards, And Product Quality Measurements

\section{Introduction}

This community service is done to encourage the community to be creative and independent with entrepreneurs. Activities can be carried out by partnering, building partnerships will make it easier and more excited. The people of Meruya Selatan village have partnered with the PKK and Menara Child-Friendly Integrated Public Space (RPTRA), also to help one of the DKI Jakarta government programs.

The community of South Meruya Village has been carrying out production activities, if there is a desire or order, for this reason, it is necessary to increase the scale of production and marketing, beginning with improvements in the production process and product quality, it is hoped that they will understand and have an awareness of the importance of product quality.

After training and assistance in the production of bags made of coffee, decorative flowers and souvenirs for SME people in Meruya Selatan village together with PKK women, they became more aware of the need to set quality standards for products made, product quality expectations of buyers / consumers to have a sustainable business business. Furthermore, it becomes important to produce sustainable products by building commitment, and producing products that meet market needs and are different from the others.

SMEs require an increase in overall product quality in accordance with the desires of market share. Businesses need to consider aspects of product quality before the goods they produce will be marketed. The condition of competitive market competition is an aspect that cannot be separated from their attention, they must compete with each other to be able to become attractive to the market. SME business people consider the quality aspect because of their awareness of consumers and prospective consumers who are more selective before making a purchasing decision.

The South Meruya community is creative and active, many handicrafts have been produced including various snacks, but they are still unable to produce large scale and sustainable. One source of the problem is not yet having an awareness of the importance of the quality of the products produced. Consumers or markets will pay attention to the quality of products to be purchased, as well as producers or craftsmen will always compete with competitors or other SME industries. Products that are easy to emulate and don't innovate will not be able to compete. Meanwhile, the products that emulate with better quality through improvements according to the wishes of consumers, will develop and kill products that are imitated, which is why the 
community service team considers it necessary to carry out business operationalization supplies to the community of South Meruya Village

\section{Problem}

Based on observations and focus group discussions (FGD) with Village Office Officials, Chairpersons and Members of the PKK, the perpetrators of UKM Rawa Buaya obtained problems: a). the community / some business owners in Meruya Selatan village do not yet have knowledge, awareness about product quality and product quality standards produced, so many products are not sustainable. b) The orientation of the business owner is still local, does not yet have the competence and commitment to further develop his business, this is due to the lack of awareness of product quality and product standards.

\section{THEORITICAL FRAMEWORK}

\section{Quality}

According to Yuri (2013: 11), the definition of quality is influenced by the subjective perspective of each person. Quality itself is considered as a relative measure of the goodness of a product or service consisting of the quality of the design or design and the quality of conformity or compatibility. Juran in Yuri (2013: 11) defines quality as fitness for purpose, which is based on the definition of quality as meeting requirements or conformity to needs. While Feigenbaum in Yuri (2013: 11) refers to quality as an overall composite of characteristics of products and services in marketing, engineering, manufacturing, and maintenance where the products and services used can meet consumer expectations. Crosby in Wahyuni (2015: 4) states that quality is goods or services that meet customer specifications or requirements. Whereas in ISO 9000, quality is the ability of a unified product, system or process characteristic to meet the stated or implied customer or related party requirements.

The main factor in realizing customer satisfaction, quality must be managed properly and correctly through several stages of the process in order to be integrated with other processes in the company (Wahyuni, 2015: 8). Juran in Juran's Quality Handbook explains that the stages in the quality process known as Juran Trilolgy consist of: a). Quality Planning, is a quality planning process that is used to meet customer needs. B). Quality Control, is the evaluation stage of quality achievement with a quality plan that has been prepared previously. c) Quality Improvement, is a process of improvement that is based on the results of the evaluation.

Shewhart issued a pragmatic concept of quality that measures of quality are a count that may be of different numerical value. Deming teaches Shewhart's principle of scientific thinking that is expressed in the Plan, Do, Check, Action (PDCA cycle) that is differentiated by the Japanese as the Deming cycle.

Then, according to David Garvin, quoted by Gaspersz (2011) and Montgomery (2009) the dimensions of product quality both consist of:

1. Performance, which is related to the functional aspects of an item and is a major characteristic that customers consider in buying the product. This dimension answers the question 'will the product fulfill the desired task?'

2. Additional features or features, namely secondary or complementary characteristics, related to product choices and their development. This dimension explains what the product can do.

3. Reliability (Reliability), which is less likely to experience damage or failure to use. In other words the success of the function in use at certain time periods and under certain conditions. This dimension discusses how often the product fails.

4. Conformance to Specification (Conformance to Specification), i.e. the extent to which design and operating characteristics meet predetermined standards. This dimension answers the question "is the product made exactly as the designer wishes?"

5. Durability (Durability), which is related to how long the product can continue to be used. This dimension answers the question 'how long does the product last?'

6. Serviceability, including speed, competence, comfort, easy to repair, satisfying complaint handling. This dimension explains the ease in repairing product damage. 
7. Aesthetics, a characteristic that is subjective, namely the attractiveness of the product to the five senses and the reflection of individual preferences. This dimension answers the question 'What does the product look like?'

8. Fit and finish, subjective nature, is related to the customer's feelings about the existence of the product as a quality product. This dimension discusses the reputation of the company making the product or the product produced.

\section{METHOD OF IMPLEMENTATION}

The activity was carried out at Rptra Menara Kelurahan Meruya Selatan, West Jakarta. UKM in Meruya Selatan Village implements business activity management as a competitive business that continues to increase and is sustainable, and is able to partner with other institutions or agencies in increasing its production. The activity starts from December 2018 - June 2019, located at Rptra Menara Meruya Selatan Village with PKK participants, prospective business actors, business actors, and community leaders.

\section{Activity Method}

Activities carried out lectures, discussions, questions and answers to convey concepts that are important to be understood and mastered by participants. The use of this method with the consideration that the lecture method combined with audio and video can provide relatively much material in a compact, fast and easy. The material provided in the form of business knowledge, production, product quality standards, product quality measurements and production management. It is expected that the delivery of material provides additional insight, understanding, awareness, and motivation to have a quality business and business sustainability. Practice and evaluation of activities carried out to see the development of business sustainability and the implementation of quality knowledge that has been received.

\section{RESULTS AND DISCUSSION}

\section{Field survey}

The initial stage of the training and training process is identified through a focus group discussion (FGD) with Village Office Officials, Chairpersons and Members of the PKK, South Meruya Village UKM actors, which are carried out at the South Meruya village office by generating information about the ability of the community of novice businesses with a variety of creativity to make bag creations from coffee wrap, flowers from plastic materials.

\section{Implementation Overview.}

Coaching is carried out by training and evaluating the implementation of training results. Training activities with 3 aspects, namely: attendance of participants, participation and seriousness of the participants and evaluation of socialization: 1) Attendance of participants: Participants in the activities are PKK ladies, UKM business actors, and callon of UKM business actors, in Meruya Selatan village, the number of participants 25 people attended as invited. 2) Participation and fun of the participants: Conditions are well implemented, as seen from the seriousness of the participants in participating in the activity until completion. Participants are very active in discussions and questions and answers that show high curiosity. Communication is carried out in both directions between the participant and the speaker / speaker. 3) Evaluation of Training, covering the extent of perceptions of PKK ladies, SMEs, and potential SME actors in guiding activities in Meruya Selatan village regarding Production, quality standards, and measurement of product quality related to UKM businesses.

The following will be evaluated on the participant profile related to the operationalization of PKK businesses and the extent of understanding and awareness of the quality of products produced by PKK mothers and SME businesses in Meruya Selatan village to maintain business sustainability.

\section{Participant Profile.}

There are 8 people who have a business and 17 people are ready to have their own business. 
Activities carried out by holding pre-test and post-test to find out knowledge, understanding, and awareness in production / business activities. Can further find out the expectations of business sustainability. As entrepreneurs will surely experience business competition, by having a commitment of course the business will continue to be sustainable.

\section{Pre-test dan post test}

\begin{tabular}{|c|c|c|c|}
\hline o & $\begin{array}{r}\text { Statement } \\
\end{array}$ & TRUE & FALSE \\
\hline & icing goods can increase family income & & \\
\hline & a product in accordance with the wishes of the buyer / prospective buyer & & \\
\hline & ng products depends on existing raw materials & & \\
\hline & roduct produced is different from other products & & \\
\hline & icts may be the same as existing products & & \\
\hline & icts produced need to be guaranteed & & \\
\hline & ction of product incompatibility for subsequent production & & \\
\hline & ict model / design after order from buyer & & \\
\hline & esulting product is durable / can be used many times & & \\
\hline & iction Speed according to buyer's expectations / according to order & & \\
\hline & ty products, if purchased, cannot be returned & & \\
\hline & tize its contents before the appearance of the product & & \\
\hline
\end{tabular}

Through filling out a simple questionnaire before giving material and training on quality standards and measurement of product quality The results of the calculation of answers / responses from 25 participants in community service, as follows:

Response Results pre- test

\begin{tabular}{|c|c|c|c|c|c|c|c|c|c|c|c|c|}
\hline Pernyataan & 1 & 2 & 3 & 4 & 5 & 6 & 7 & 8 & 9 & 10 & 11 & 12 \\
\hline Salah & 2 & 3 & 13 & 2 & 6 & 4 & 4 & 10 & 5 & 0 & 2 & 13 \\
\hline Benar & 23 & 22 & 12 & 23 & 19 & 21 & 21 & 15 & 20 & 25 & 23 & 12 \\
\hline & & & & & & & & & & & & \\
\hline Salah & $8 \%$ & $12 \%$ & $52 \%$ & $8 \%$ & $24 \%$ & $16 \%$ & $16 \%$ & $40 \%$ & $20 \%$ & $0 \%$ & $8 \%$ & $52 \%$ \\
\hline Benar & $92 \%$ & $88 \%$ & $48 \%$ & $92 \%$ & $76 \%$ & $84 \%$ & $84 \%$ & $60 \%$ & $80 \%$ & $100 \%$ & $92 \%$ & $48 \%$ \\
\hline
\end{tabular}

Response Results post -test

\begin{tabular}{|c|c|c|c|c|c|c|c|c|c|c|c|c|}
\hline Post-test & 1 & 2 & 3 & 4 & 5 & 6 & 7 & 8 & 9 & 10 & 11 & 12 \\
\hline Salah & 0 & 1 & 5 & 2 & $\mathbf{1 5}$ & 3 & $\mathbf{1 2}$ & $\mathbf{1 3}$ & 3 & 0 & 16 & $\mathbf{1 7}$ \\
\hline Benar & $\mathbf{2 5}$ & $\mathbf{2 4}$ & $\mathbf{2 0}$ & $\mathbf{2 3}$ & 10 & $\mathbf{2 2}$ & 13 & 12 & 22 & 25 & 9 & 8 \\
\hline
\end{tabular}

Filling the pre-test, the response has not shown understanding and awareness of product quality, does not yet understand the determination of product quality standards. Consumer expectations become one of the tools to determine quality standards that will be produced. Understanding standards and measuring product quality is important for production activities, so that the products produced continue to be in demand by consumers, so that business activities will be sustainable. These conditions need to be given training and coaching in production activities, determining quality standards, measuring product quality

The results of the post-test filling indicate a difference after giving a presentation on the operationalization of business for PKK women in RPTRA of Meruya Selatan. There is a decrease in numbers and the percentage of lack of knowledge, understanding related to standards and measurement of product quality based on participant responses.

Coaching begins with the provision of material production activities, determine and measure product quality. The activities are as follows: 

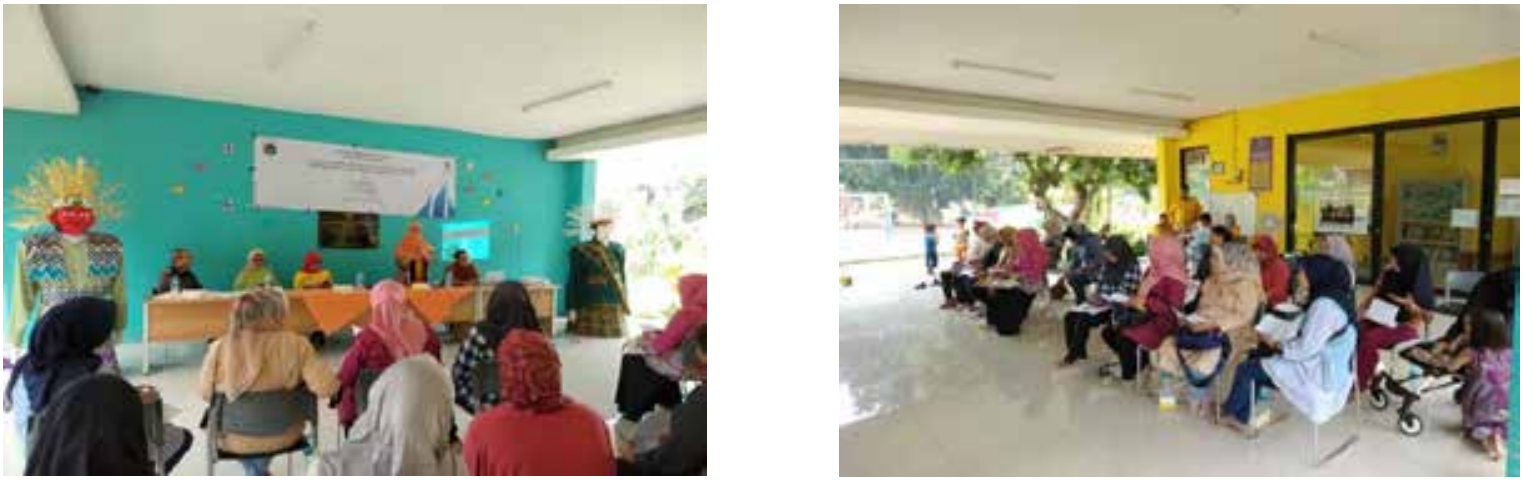

Training and coaching activities with the delivery of material production activities for understanding and awareness of product quality and measurement, is expected to increase understanding and awareness of product quality is important. So PKK ladies and trainees in general need the importance of quality before making products produced for consumers.

Understanding and awareness of product quality can develop businesses that are sustainable. In the material delivery activities are carried out interactively and passionately. PKK mothers and pesert generally have a high curiosity. The enthusiasm of participants that needs to be fostered continues to be committed and sustainable.

Training and coaching activities with the delivery of material production activities for understanding and awareness of product quality and measurement, is expected to increase understanding and awareness of product quality is important. So PKK ladies and trainees in general need the importance of quality before making products produced for consumers.

Understanding and awareness of product quality can develop businesses that are sustainable. In the material delivery activities are carried out interactively and passionately. PKK mothers and pesert generally have a high curiosity. The enthusiasm of participants that needs to be fostered continues to be committed and sustainable.
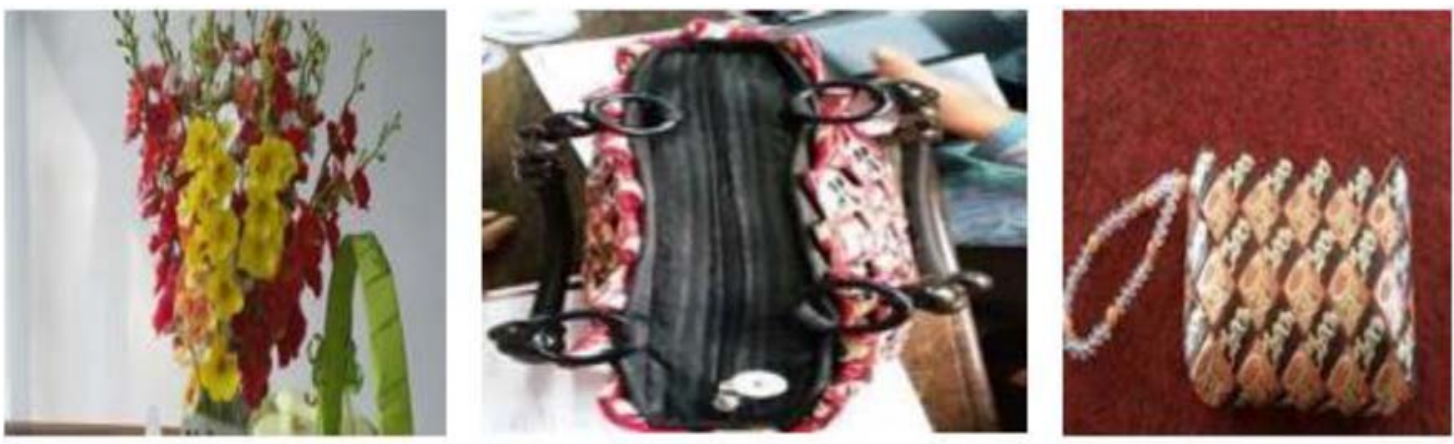

Picture: Creation of PKK ladies

Innovation and creativity in making bags made of coffee, decorative flowers and souvenirs carried out by the community in the Meruya Selatan village. Coaching is still needed to be committed and sustainable and needs to be reminded about the mindset of an entrepreneur, among others, increasing turnover and developing. In business practices and coaching evaluation activities, participants who understand the importance of quality standards and measurements have begun to communicate with consumers and partners to assess their production results. This activity also gives encouragement to craftsmen / entrepreneurs. Coaching is done continuously considering P2M Mercubuana University has collaborated with the Meruya Selatan village. 


\section{Conclusion}

Based on a series of activities fostering the quality control of SME products will be quality standards and measurements of the results of business production in SMEs with the aim of having a quality product. As a result of quality products, sustainable businesses will be realized. Businesses with quality products are also an evaluation tool on the explanation of building competencies and commitments to have an SME business in Meruya Selatan village, West Jakarta, it can be concluded:

1. Participants understand and have an awareness that production activities / business operations are important in producing quality products in order to be affected by business sustainability. The most important elements in building a sustainable handicraft business from coffee packs and various flowers are:

a. The ability to understand the production process in a sustainable manner, from the supplier of raw materials to the product being realized ..

b. Participants consisting of PKK ladies in South Meruya village and several community leaders if they wish to have quality production. This needs to determine quality standards and measurements.

c. The ability to produce goods continuously in order to support the achievement of the success of SME businesses

2. Participants understand the need for quality products as an element of business sustainability in SMEs. The most important elements in building a commitment to having a business that is business sustainability are:

a. Readiness produces different products from the others.

b. Understand the vision, clear goals, production commitments according to market needs.

\section{Suggestions}

1. The need for assistance from partners or organizations such as the PKK to help strengthen the commitment of production that has sustainability.

2. $68 \%$ of training and coaching participants are still potential business owners, they still need strong encouragement and intensive assistance to remind and encourage the realization of a business.

\section{References}

Alma Buchari; Kewirausahaan, Edisi Reviai. Bandung : Alfabeta, 2006.

Curtis, Susan; and Dennis Wright. Retaining Employes- The Fast Track to Commitment, Management Reserach News, Volume 24.

Gibson, James L.; Ivancevich, Jhon M.; Donelly, James H.;Konopaske, Rober. Organization, Bahavior, Structure, Process, Edisi $13^{\text {th }}$ ed. Boston : McGraw-Hill (2009)

Hjelle, Larry A. \& Daniel J. Ziegler (ed). Personality Theories. New York : McGraw-Hill Inc., 1992.

Sawarni Hasibuan, Mirza, dan Zulfa Fitri Ikatrinasari, Jurnal Sinergitas PkM \& CSR Vol.2, No.1, Oktober 2017 P-ISSN: 2528-7052 E-ISSN:2528-7184

Shermon ,Ganesh. Competrency Based HRM, A Strategic Resource for Competency Mapping Assessment and Development Centres, New delhi :Tata McGraw Hill Education Private Limited, 2004.

Sopiah. Perilaku Organisasi.Yogtyakarta : Andi. 2008.

Suparman, M. Atwi, Desain Instruksional Modern. Jakarta : Erlangga, 2002.

Uno , Hamzah B., Masri Kudrat Umar, Kaysar Panjaitan. Variabel Penelitian Dalam Pendidikan Dan Pembelajaran. Jakarta : PT Ini Publikatama, 2014.

http://enterpreuneurship.blogspot.co.id/2011/12/karakter-seorang-wirausaha-pada.html 